\author{
(online) $=$ ISSN $2285-3642$ \\ ISSN-L = $2285-3642$ \\ Journal of Economic Development, Environment and People \\ Volume 10, Issue 4, 2021 \\ URL: http://jedep.spiruharet.ro \\ e-mail: office jedep@spiruharet.ro
}

\title{
Determination of Financial Literacy Level: A Study on Hitit University Faculty of Economics and Administrative Sciences Students ${ }^{1}$
}

\author{
Selcuk Kendirli+ ${ }^{1}$, Muhammet Selcuk Kaya ${ }^{2}$, Aykut Isleyen ${ }^{3}$ \\ ${ }^{1}$ Prof. Dr.(Ph.D.), Hitit University, FEAS, Finance and Banking Department, Corum, Turkey \\ ${ }^{2}$ Hitit University, FEAS, Finance and Banking Department, Corum, Turkey \\ ${ }^{3}$ Hitit University, FEAS, Business Department, Corum, Turkey.
}

\begin{abstract}
Financial literacy is the level of financial knowledge, attitude and behavior that enables individuals to manage their income, expenses and assets in a way that does not cause financial problems both today and in the future. As individuals' financial literacy levels increase, unnecessary consumption and waste of resources will decrease and the efficiency of investments will increase. Increasing the level of financial literacy will ensure a more balanced formation of asset prices in financial markets and prevent the formation of price bubbles in the markets. Today, financial markets around the world are almost integrated, financial transactions have become possible quickly through portable electronic devices. In this environment, the difference in welfare between individuals and societies with financial literacy and individuals and societies without financial literacy has increased more than in any other period in history. This study, it is aimed to measure the financial literacy level of the students of Hitit University Faculty of Economics and Administrative Sciences located in the province of Çorum. The data of the study were obtained from a questionnaire with the participation of 400 students studying in 5 different departments. By using the percentages of the correct answers given to the questions, success scores were created based on departments. With the help of the T-test and ANOVA tests, the relationship between students' financial literacy and whether they use department, gender, class, and credit card was determined. As a result of the study, it was determined that there are significant relationships between the departments and classes in which students study and their financial literacy, and no significant relationships were found between their credit card and internet banking usage and gender and financial literacy.
\end{abstract}

Keywords: Financial Literacy, Personal Finance, Finance Education.

JEL Codes: G53, 122.

How to cite: Kendirli, S., Kaya, M., \& Isleyen, A. (2021). Determination of Financial Literacy Level: A Study on Hitit University Faculty of Economics and Administrative Sciences Students. Journal of Economic Development, Environment and People, 10(4), 29-41. doi:http://dx.doi.org/10.26458/jedep.v10i4.714

\footnotetext{
${ }^{1}$ This study was created by updating and improving the paper presented at the international conference called Business \& Organization Research held in Safranbolu between 12-14 September 2018 by the authors..
}

+Corresponding author Tel. : +90 542 3239238; E-mail address: selcukkendirli@yahoo.com, selcukkendirli@hitit.edu.tr 


\author{
(online) = ISSN $2285-3642$ \\ ISSN-L = 2285 - 3642 \\ Journal of Economic Development, Environment and People \\ Volume 10, Issue 4, 2021 \\ URL: http://jedep.spiruharet.ro \\ e-mail: office jedep@spiruharet.ro
}

\title{
1. Introduction
}

Financial literacy, in short, is having the knowledge and skills that enable you to make the right financial decisions. In today's economies, where product diversity in financial markets is increasing day by day, the importance of financial literacy is increasing day by day. The ability of individuals to make the right financial decisions will both increase their individual welfare level and have positive effects on the economies of the countries they are citizens of. Increasing financial literacy will help financial markets to function effectively. In addition, since financially literate individuals are less likely to react prematurely and excessively to changes in the market, they also alleviate the turbulences and fluctuations in the market (Hayta, 2011: 252). For this reason, in recent years, the concept of financial literacy has been emphasized, and governments and academics have been conducting research to determine and increase the financial literacy levels of individuals.

In today's difficult economic conditions, individuals are faced with complex financial decisions at a young age, and financial mistakes made in the early stages of life can have huge costs. Teenagers hold large amounts of student loan debt, or credit card debt, causing their savings to decline. Understanding the factors that contribute to, or arising from, the acquisition of financial information can help decision-makers design effective targeted interventions on the youth population (Lusardi 2010).

It is important for university students, most of who have started to live separately from their families for the first time in their lives, to manage their limited budget correctly and to have a smooth and productive university life. Faculties of Economics and Administrative Sciences are the faculties that are expected to have the highest level of financial literacy in terms of their curricula. Financial literacy studies in the Faculties of Economics and Administrative Sciences will also measure the effectiveness of the course curriculum on financial literacy.

This study aimed to measure the financial knowledge and skill levels of the students of the Faculty of Economics and Administrative Sciences of Hitit University, studying in different departments and aged between 19-25 years. In addition to the effect of the students' departments on their financial literacy, the relationship with their financial literacy was revealed with the help of variables such as class, age, gender, credit card use, internet banking use. According to the results obtained from the study, the average success score of all participants was found to be 47 . The average achievement score of male students was 49 , and the average achievement score of female students was 45 . As a result of the t-test, no significant difference was found between the scores of male and female students. According to the results obtained, it has been determined that female students have lower financial literacy than male students. According to the findings obtained from the study, it has been determined that the students of the Faculty of Economics and Administrative Sciences of Hitit University do not have sufficient knowledge of basic finance. According to these results, it is necessary to enrich the faculty curricula with courses that will provide students with investment and finance information.

\section{Literature Review}




\author{
(online) = ISSN $2285-3642$ \\ ISSN-L = $2285-3642$ \\ Journal of Economic Development, Environment and People \\ Volume 10, Issue 4, 2021 \\ URL: http://jedep.spiruharet.ro \\ e-mail: office jedep@spiruharet.ro
}

Chen and Volpe (1998), as a result of their financial literacy research on 924 students on 14 college campuses in the United States, concluded that although the questions posed to university students are simple, the rate of correct answers is around $53 \%$, and the financial literacy of university students should be improved. . The researchers divided the questions that students used to measure their financial literacy into savings, investment, lending, insurance and basic information groups. They determined that the rate of correct answers did not exceed $65 \%$ in any group of questions. In addition, the researchers found that business students have lower financial literacy than other students, women, men, those with no work experience, those with work experience, those studying in the lower classes, those studying in the upper classes, those under the age of 30 and those over the age of 30.

Bayram (2014), as a result of his study to determine the financial literacy of Anadolu University FEAS and Porsuk Vocational School students, determined that the financial literacy of the students is low in general, but they are not aware of this situation. He found that the financial literacy of FEAS students is higher than that of Porsuk Vocational School students, indicating that this is because FEAS students take finance-related courses. In addition, the rate of students using credit cards is $46.8 \%$, while those using online banking services are $35 \%$.

Ergün et al. (2014) stated that the students who participated in their study on Osmaniye Korkut Ata University FEAS Department of Business Administration students could be concluded that although they have basic financial literacy, they are not financially literate at an advanced level. As a result of the research, no significant relationship was found between the students' grades, grade point averages, and the educational status of their families and their financial literacy.

Kilıç et al. (2015), as a result of their study on students studying at different faculties at Gaziantep University, found that all university students had low financial literacy levels. In addition, they determined that among the students participating in the study, the male students had higher financial literacy. Among the different faculties, they concluded that the faculty with the highest financial literacy was the Faculty of Economics and Administrative Sciences, and the faculty with the lowest financial literacy was the Faculty of Architecture.

Agnew and Harrison (2015) found that male students had higher financial literacy than female students, as a result of their study on students from two universities, one in New Zealand and the other in England. Another important finding of the researchers is that the subject on which male students are significantly more knowledgeable than female students is compound interest. Lusardi and Mitchell (2008) found that male students are more knowledgeable than female students about compound interest.

Elvan and Demir (2015), as a result of the financial literacy research they conducted on the academic staff of Süleyman Demirel University, determined that among the academicians, the financial literacy is at the level of $59 \%$ and this level is lower than the Turkey average of $59.8 \%$. They also concluded that among academics, an increase in income level did not increase financial literacy, whereas academics with lower incomes had higher financial literacy.

Sezer and Demir (2015), in their study to determine the relationship between financial literacy and cognitive ability levels of investors and psychological illusions, determined that although $87 \%$ of the participants were graduated from higher education institutions, their financial literacy levels were 


\author{
(online) = ISSN $2285-3642$ \\ ISSN-L = $2285-3642$ \\ Journal of Economic Development, Environment and People \\ Volume 10, Issue 4, 2021 \\ URL: http://jedep.spiruharet.ro \\ e-mail: office jedep@spiruharet.ro
}

extremely low. They also found that investors' falling into psychological illusions is independent of their level of financial literacy.

Karaa and Kuğu (2015), as a result of their study on 916 students studying in different departments of a state university, found that financial literacy levels of students were related to age, gender and the department they studied, but there was a significant difference between family education, income level and general grade point average. They determined that there was no relationship. As a result of the research, it was determined that the general financial literacy level of the students is low, the financial literacy of the upper classes is higher than the lower classes, the financial literacy increases as the age increases, and the financial literacy levels of the students studying in the departments related to economics are high.

Barmaki (2015), in a study of 500 undergraduate students studying at Hacettepe University, asked questions to measure basic money knowledge, knowledge of concepts on income, money management knowledge, savings and investment knowledge, and spending and borrowing knowledge. As a result of this research, it was determined that the general financial literacy level obtained from the averages of the correct answers given by the students was $53.62 \%$. In addition, male students are more successful in knowledge about basic money knowledge and income concepts, that those studying in the fields of humanities and arts have lower knowledge of basic money knowledge, savings and investment compared to other departments, and monthly family income is $1000 \mathrm{TL}$ and It has been determined that the knowledge of the students under the income level about the concepts of income is lower than the students from other income families.

Rosacker and Rosacker (2016) asked 25 questions to 223 FEAS students, which they divided into groups such as income sources, credit cards, interest rates, savings tools, risk management, credit problems, and asked students about credit problems, credit cards and financial instruments. concluded that they were insufficient. In addition, they found that the answers given to any of the question groups did not have a significant relationship with the gender variable.

Biçer and Altan (2016) examined the financial literacy levels of Cumhuriyet University Faculty of Health Sciences students in the dimensions of spending, perception, interest and attitude, and found significant differences in the sub-dimensions of the financial literacy scale among students from different departments who participated in the research. In addition, as a result of the research, the financial perceptions of the students who received financial education were found to be higher than the financial perceptions of the students who did not receive financial education.

Basarir and Sarihan (2017) measured the financial literacy level of 407 students from Bandırma University, Faculty of Economics and Administrative Sciences and Faculty of Applied Sciences, selected by simple random sampling method, with the financial literacy scale developed by Kılıç, Ata and Seyrek (2015). . The researchers determined that among the departments, econometrics students had the highest degree of financial literacy with $65 \%$, followed by the students of the department of economics with $62 \%$, the students of the finance department with a score of $59 \%$, and the students of the department of business administration with a score of $58 \%$. they have done. They determined that the students of the international trade and logistics department were in last place with $52 \%$. As a result of the research, the general financial literacy level of the students was found to be $58 \%$. 


\author{
(online) $=$ ISSN $2285-3642$ \\ ISSN-L = $2285-3642$ \\ Journal of Economic Development, Environment and People \\ Volume 10, Issue 4, 2021 \\ URL: http://jedep.spiruharet.ro \\ e-mail: office jedep@spiruharet.ro
}

Kocabıyık and Teker (2018), as a result of their study to determine the financial literacy level of students studying at Süleyman Demirel University, found that male students, female students, and students studying in economic and administrative programs have higher financial literacy levels than students studying in other programs.

Karadeniz et al. (2019), as a result of the financial literacy research they conducted on 440 university students studying at Kafkas University in the 2017-2018 academic year, found that 22\% of the students had a low level, $51 \%$ a medium level and only $27 \%$ had an advanced level of financial literacy. found to be literate. In addition, they found that $49 \%$ of the students were successful in managing their financial situation, $45 \%$ were moderately successful in managing their financial situation, and $5.6 \%$ were successful at a low level. Another finding of the study is that the students stated that their financial situation was not at the level to invest in investment instruments, and therefore they were not interested in investment instruments.

Ak Bingül, Türk and Ak (2020) conducted a study on 558 students studying at Kırklareli University, using the survey method. As a result of the research, it was determined that the variables of the region they live in, gender, educational status of their parents and educational status did not have a significant relationship with the financial literacy of the students, on the contrary, the departments they studied had a significant relationship with the financial literacy of the students. According to the research findings, the financial literacy levels of the students of the faculty of economics and sciences are higher than the financial literacy levels of the students studying in other faculties. When the students were classified in terms of gender, they found that the number of questions that male students answered correctly was higher than that of female students, and that the questions to which female students answered "I have no idea" were proportionally higher than those of male students. According to the researchers, the general financial literacy levels of the students participating in the survey are not at the desired and expected levels.

Alkan et al. (2020), as a result of their research on 1008 students studying at Atatürk University, found that male students, female students, students over the age of 25 , students under the age of 25 , students whose monthly income is higher than $1250 \mathrm{TL}$, monthly income is $1250 \mathrm{TL}$. They found that students who are less than.

Anbar and Beridze (2020) conducted a financial literacy questionnaire on 314 students from Bursa Uludağ University FEAS and 269 students from the Faculty of Economics and Administrative Sciences from two universities in Georgia. In the questionnaire, they measured the financial literacy of the students with the dimensions of financial attitude, financial behavior and financial knowledge. In the study, students were divided into two groups as low and high financial literacy. They found that $54 \%$ of students in Turkey have high financial literacy and $44 \%$ of students in Georgia have high financial literacy. In the sub-dimensions of financial literacy, it has been determined that students in Turkey have higher scores in terms of financial knowledge and financial attitude, and students in Georgia have higher scores in terms of financial behavior.

Baltacı and Kütük (2020), as a result of their research on state university students in the Eastern Black Sea Region, found that male students have higher financial literacy than female students, married students, single students, and students studying in economic and administrative programs have higher levels of financial literacy than other students. In addition, it has been determined that those studying in the final year have a higher level of financial literacy than those studying in other classes. According to the 


\author{
(online) = ISSN $2285-3642$ \\ ISSN-L = 2285 - 3642 \\ Journal of Economic Development, Environment and People \\ Volume 10, Issue 4, 2021 \\ URL: http://jedep.spiruharet.ro \\ e-mail: office jedep@spiruharet.ro
}

researchers, the results of the study revealed that the overall financial literacy level of the participants was low.

Kaya and Güneş (2020), as a result of their research on Burdur Mehmet Akif Ersoy University FEAS Banking and Finance Department students, found that $9 \%$ of the students were at a very low level, $37.2 \%$ at a low level, and $47.3 \%$ at a medium level. they found that only $6.5 \%$ had a high level of financial literacy. The researchers also determined that male students, female students, internet banking users, non-users, credit card users, non-credit card users, students who buy and sell foreign currency have higher financial literacy scores than students who do not buy and sell foreign currency.

Thomas and Subshashree (2020), as a result of their study on engineering faculty students in India, determined that the financial literacy levels of the students participating in the research were low. In addition, with their data analysis, it was determined that financial knowledge, financial attitude, parental effect and peer group effect had a direct and positive effect on the level of financial literacy among undergraduate engineering students.

Uyar and Atalay (2021), in their study on Alanya Alaaddin Keykubat University FEAS students, found that there was no significant relationship between the courses they took, their gender, and their financial literacy. They found that there is a significant relationship between students' grade point averages, their subjective evaluations of their financial literacy, and their financial literacy. According to the assessment made by the researchers, the financial literacy levels of the students are low. In the study, they found that students who successfully completed the first year of compulsory finance courses had higher financial literacy than other students.

\title{
3. Data and Method
}

The research was conducted on a sample of 400 students, 80 of each, from five different departments, studying at Hitit University FEAS in the spring term of 2017-2018. The data of the research were collected through face-to-face interviews with the participants, consisting of 7 questions to measure economic knowledge, 4 questions to measure tax and regulatory knowledge, 5 questions to measure retail banking information, and 13 questions to measure savings, investment and general finance knowledge. has been obtained. The study of Kılıç and Seyrek (2015) was used in the creation of the question categories and question templates used in the survey. The data obtained from the questionnaires were loaded into the SPSS statistical program and analyzed with the help of this program. To determine the factors affecting the financial literacy levels of the participants, the following hypotheses were determined and tested.

$H_{1}$ : The financial literacy levels of the participants differ according to the departments they study. $\mathrm{H}_{2}$ : There is a significant relationship between the gender of the participants and their level of financial literacy.

$H_{3}$ : The financial literacy levels of the participants differ according to the classes they study.

$\mathrm{H}_{4}$ : Financial literacy of participants using credit cards differs from students who do not use credit cards.

$H_{5}$ : There is a significant difference between the financial literacy levels of the participants who use internet banking and the financial literacy levels of the participants who do not use internet banking. 


\author{
(online) = ISSN $2285-3642$ \\ ISSN-L = $2285-3642$ \\ Journal of Economic Development, Environment and People \\ Volume 10, Issue 4, 2021 \\ URL: http://jedep.spiruharet.ro \\ e-mail: office jedep@spiruharet.ro
}

\title{
4. Findings
}

Of the students participating in the study, 162 (41\%) were male and $238(59 \%)$ were female. $49 \%$ of the students are in the 3 rd grade, $26 \%$ are in the 4 th grade, $20 \%$ are in the 2 nd grade and $5 \%$ are in the 1 st grade. The average age of the students is 21.51 and $83 \%$ of them are between 20 and 23 years old. The rate of those who use credit cards is $62 \%$, the rate of those who use internet banking is $78 \%$, and the rate of those who have a private pension account is $5 \%$.

In the survey, success scores were created for each question group by using the percentages of correct answers given to the questions to measure the level of financial literacy. In Table 1, the weighted average achievement scores of all participants in each question group and the weighted average achievement scores for each subgroup are summarized.

Table.1: Average Achievement Scores of Participants

\begin{tabular}{|c|c|c|c|c|c|c|c|}
\hline & & Economy & $\begin{array}{l}\text { Tax and } \\
\text { Legislation }\end{array}$ & $\begin{array}{l}\text { Retail } \\
\text { Banking }\end{array}$ & $\begin{array}{l}\text { Investment } \\
\text { Finance }\end{array}$ & $\begin{array}{l}\text { Financial } \\
\text { Calculation }\end{array}$ & $\begin{array}{l}\text { Average Success } \\
\text { Score }\end{array}$ \\
\hline \multicolumn{2}{|c|}{ All participants } & 48 & 58 & 48 & 41 & 52 & 47 \\
\hline \multirow[t]{2}{*}{ Gender } & Male & 48 & 63 & 50 & 45 & 56 & 49 \\
\hline & Female & 49 & 56 & 46 & 41 & 50 & 45 \\
\hline \multirow[t]{5}{*}{ Department } & Business & 42 & 54 & 43 & 40 & 53 & 43 \\
\hline & Public Finance & 44 & 63 & 43 & 36 & 53 & 44 \\
\hline & Economy & 48 & 64 & 49 & 45 & 55 & 49 \\
\hline & $\begin{array}{l}\text { Political science and } \\
\text { public } \\
\text { administration } \\
\text { (PSPA) }\end{array}$ & 39 & 53 & 43 & 32 & 44 & 39 \\
\hline & Banking and Finance & 68 & 57 & 61 & 59 & 56 & 59 \\
\hline \multirow[t]{4}{*}{ Class } & 1 & 42 & 46 & 29 & 26 & 25 & 31 \\
\hline & 2 & 47 & 60 & 43 & 45 & 47 & 46 \\
\hline & 3 & 46 & 55 & 48 & 40 & 54 & 45 \\
\hline & 4 & 54 & 67 & 55 & 49 & 58 & 53 \\
\hline \multirow[t]{2}{*}{ Credit Card } & Uses & 49 & 58 & 50 & 45 & 56 & 48 \\
\hline & Non use & 46 & 58 & 45 & 39 & 46 & 44 \\
\hline \multirow[t]{2}{*}{$\begin{array}{l}\text { Internet } \\
\text { Banking }\end{array}$} & Use & 48 & 58 & 49 & 41 & 54 & 47 \\
\hline & Non use & 48 & 58 & 43 & 46 & 46 & 47 \\
\hline
\end{tabular}

The general financial literacy score of the students participating in the research was determined as 47 . The financial literacy score of male students is 49 and female students are 45 . As a result of the research, it is seen that the financial literacy of the students increases in parallel with the class they are in. It is seen that the fourth year students, that is, the last year students, have the highest financial literacy with 53 points, while the first year students have 31 points. In addition, none of the first-year students surveyed scored above 50 points. 


\author{
(online) $=$ ISSN $2285-3642$ \\ ISSN-L = 2285 - 3642 \\ Journal of Economic Development, Environment and People \\ Volume 10, Issue 4, 2021 \\ URL: http://jedep.spiruharet.ro \\ e-mail: office jedep@spiruharet.ro
}

Looking at the scores of the departments, it was revealed that the Department of Banking and Finance had the highest financial literacy with 59 points. It is seen that the Department of Economics ranks second with 49 points. It is seen that the public finance department and the business administration departments take the third place with 44 points, respectively. It is seen that the department of political science and public administration is in the last place with 39 points.

The rate of students using credit cards was 62\%, and the average success score of those using credit cards was 48 . The success scores of credit card users are 4 points higher than the average success scores of those who do not use credit cards. The success scores of those who use internet banking are the same as those who do not use internet banking.

\title{
4.1. The Relationship between Gender and Financial Literacy
}

The average of financial literacy achievement scores of male students was calculated as 48.83 . The average of financial literacy achievement score of female students was found to be 45.3 . In order to determine whether there is a significant difference between the financial literacy of students of different genders, a t-test was conducted. Since the P-value found as a result of the test is greater than 0.05 , it is seen that there is no significant difference between male and female students in terms of financial literacy levels at the $95 \%$ confidence level.

\begin{tabular}{|l|l|l|}
\hline & Male & Female \\
\hline Number of Participant & 162 & 238 \\
\hline Average Point & 48,83 & 45,30 \\
\hline T Value & & 1,653 \\
\hline P Value & & 0,1 \\
\hline
\end{tabular}

\subsection{The relationship between credit card use and internet banking use and financial literacy}

Among the participants, the average of the success scores of the credit card users was calculated as 48.2. The average of success scores of those who do not use credit cards was found to be 44.33 . Since the P-value found as a result of the t-test performed to determine whether there is a significant difference in financial literacy between those who use credit cards and those who do not use credit cards, is greater than 0.05. There is no significant difference at the $95 \%$ confidence level.

\begin{tabular}{|l|r|r|}
\hline & Using Credit Card & \multicolumn{2}{|l|}{$\begin{array}{l}\text { Not Using Credit } \\
\text { Card }\end{array}$} \\
\hline Number of Participant & 248 & 152 \\
\hline Average Point & 48,2 & 44,33 \\
\hline T Value & \multicolumn{2}{|c|}{1,798} \\
\hline P Value & \multicolumn{2}{|c}{0,074} \\
\hline
\end{tabular}

Among the participants, the average of the success scores of the internet banking users was calculated as 46,63 . The average of success scores of those who do not use internet banking was found to be 47,07 .

\begin{tabular}{|l|l|l|}
\hline & $\begin{array}{l}\text { Using Internet } \\
\text { Banking }\end{array}$ & $\begin{array}{l}\text { Not Using Internet } \\
\text { Banking }\end{array}$ \\
\hline Number of Participant & 310 & 90 \\
\hline
\end{tabular}




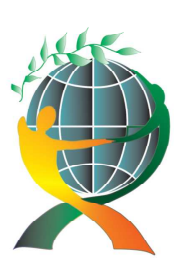

$$
\begin{gathered}
\text { (online) }=\text { ISSN } 2285-3642 \\
\text { ISSN-L = 2285 - } 3642
\end{gathered}
$$

Journal of Economic Development, Environment and People

Volume 10, Issue 4, 2021

URL: http://jedep.spiruharet.ro

e-mail: office jedep@spiruharet.ro

\begin{tabular}{|l|r|r|}
\hline Average Point & 46,63 & 47,07 \\
\hline T Value & \multicolumn{2}{|c|}{} \\
\hline P Value & \multicolumn{2}{|c|}{} \\
\hline
\end{tabular}

As a result of the $t$ test, no significant difference was found between the financial literacy levels of the participants who use internet banking and those who do not.

\subsection{The Relationship between the Department of Students and their Financial Literacy}

As a result of the examination of the participants by dividing them into the departments they studied, it was determined that there were significant differences between the departments in terms of financial literacy scores. Some statistics on financial literacy achievement scores of departments are given below.

\begin{tabular}{|l|r|r|r|r|r|}
\hline \multicolumn{1}{|c|}{ Department } & Number & $\begin{array}{c}\text { Average } \\
\text { Satisfaction Point }\end{array}$ & $\begin{array}{c}\text { Standard } \\
\text { Deviation }\end{array}$ & Highest & Lowest \\
\hline Business & 80 & 42,88 & 13,476 & 17 & 76 \\
\hline Public Finance & 80 & 43,80 & 12,464 & 17 & 72 \\
\hline Economy & 80 & 49,18 & 10,605 & 24 & 72 \\
\hline Political science and public administration & 80 & 39,18 & 16,456 & 10 & 79 \\
\hline Banking and Finance & 80 & 58,63 & 13,200 & 28 & 93 \\
\hline All Departments & 400 & 46,73 & 14,870 & 10 & 93 \\
\hline
\end{tabular}

ANOVA test was conducted to find out whether there is a relationship between the students' department and their financial literacy. As a result of the ANOVA test, it was determined that there was a significant relationship between the students' departments and their financial literacy.

\begin{tabular}{|r|l|l|}
\hline Student Number & F Value & ANOVA Test P Value \\
\hline 400 & 12,745 & 0,000 \\
\hline
\end{tabular}

Due to the significant results obtained in the ANOVA analysis of variance, the TUKEY test was also used to measure the financial literacy difference between the departments. As a result of the TUKEY test, it was revealed that the difference between the financial literacy score of the banking and finance department and the financial literacy scores of all departments was significant. Among other departments, only the difference between Economics and Political Science and Public Administration departments was found to be significant.

\begin{tabular}{|l|l|r|r|}
\hline Department & Department & \multicolumn{1}{l|}{$\begin{array}{l}\text { Mean } \\
\text { Difference }\end{array}$} & \multicolumn{1}{l|}{ Significance } \\
\hline \multirow{4}{*}{ Business } & &,- 925 &, 221 \\
\cline { 2 - 4 } & Eublic Finance & $-6,300$ &, 730 \\
\cline { 2 - 4 } & PSPA & 3,700 &, 000 \\
\cline { 2 - 4 } & Finance and Banking & $-15,750^{*}$ &, 925 \\
\hline Public Finance & Business & $-5,375$ &, 378 \\
\cline { 2 - 4 } & Economy & 4,625 &, 534 \\
\cline { 2 - 4 } & PSPA &, 998 \\
\hline
\end{tabular}


(online) = ISSN $2285-3642$

ISSN-L = $2285-3642$

Journal of Economic Development, Environment and People

Volume 10, Issue 4, 2021

URL: http://jedep.spiruharet.ro

e-mail: office jedep@spiruharet.ro

\begin{tabular}{|l|l|r|r|}
\hline \multirow{5}{*}{ Economy } & Finance and Banking & $-14,825^{*}$ &, 000 \\
& Business & 6,300 &, 221 \\
\cline { 2 - 4 } & Public Finance & 5,375 &, 378 \\
\cline { 2 - 4 } & PSPA & $10,000^{*}$ &, 009 \\
\cline { 2 - 4 } & Finance and Banking & $-9,450^{*}$ &, 016 \\
\hline \multirow{3}{*}{$\begin{array}{l}\text { Political science and public administration } \\
\text { (PSPA) }\end{array}$} & Business & $-3,700$ &, 730 \\
\cline { 2 - 4 } & Public Finance & $-4,625$ &, 534 \\
\cline { 2 - 4 } & Economy & $-10,000^{*}$ &, 009 \\
\cline { 2 - 4 } & Finance and Banking & $19,450^{*}$ &, 000 \\
\hline Finance and banking & Business & $14,750^{*}$ &, 000 \\
\cline { 2 - 4 } & Public Finance & $9,825^{*}$ &, 000 \\
\cline { 2 - 4 } & Economy & $19,450^{*}$ &, 016 \\
\cline { 2 - 4 } & PSPA & 900 \\
\hline
\end{tabular}

* The mean difference is significant at the 0.05 confidence level.

\subsection{The Relationship Between Students' Grades and Their Financial Literacy}

ANOVA analysis of variance was also conducted to determine whether there was a significant relationship between students' grades and financial literacy levels. As a result of the ANOVA analysis of variance, it was determined that there was a significant difference between the grades of the students and their financial literacy.

\begin{tabular}{|r|l|lr|}
\hline \multicolumn{1}{|l|}{ Student Number } & F Value & ANOVA Test P-Value & \\
\hline 400 & & 8,586 & \\
\hline
\end{tabular}

Due to the significant results obtained in the ANOVA analysis of variance, the TUKEY test was also used to measure the financial literacy difference between the classes. As a result of the TUKEY test, there is a significant difference between the financial literacy achievement scores of the 1st year students and the financial literacy achievement scores of the students in all other classes. In addition, it has been determined that there is a significant difference between the financial literacy achievement scores of the 4th-grade students and the financial literacy achievement scores of the 4 th-grade students.

\begin{tabular}{|c|c|c|c|}
\hline CLASS & CLASS & Mean Difference & Significance \\
\hline \multirow[t]{3}{*}{ 1st Class } & 2nd Class & $-15,068^{*}$ & ,010 \\
\hline & 3rd Class & $-14,053^{*}$ & ,011 \\
\hline & 4th Class & $-22,152^{*}$ & ,000 \\
\hline \multirow[t]{3}{*}{ 2nd Class } & 1 st Class & $15,068^{*}$ & 010 \\
\hline & 3rd Class & 1,015 & 981 \\
\hline & 4th Class & $-7,083$ & ,084 \\
\hline 3rd Class & 1 st Class & $14,053^{*}$ & ,011 \\
\hline
\end{tabular}




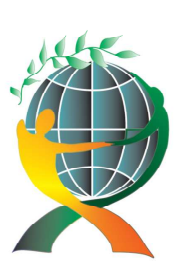

\author{
(online) $=$ ISSN $2285-3642$ \\ ISSN-L = 2285 - 3642 \\ Journal of Economic Development, Environment and People \\ Volume 10, Issue 4, 2021
}

URL: $\underline{\text { http://jedep.spiruharet.ro }}$

e-mail: office jedep@spiruharet.ro

\begin{tabular}{|l|l|r|r|}
\hline \multirow{4}{*}{4} & 2nd Class & $-1,015$ &, 981 \\
\cline { 2 - 4 } & 4th Class & $-8,099^{*}$ &, 006 \\
\hline \multirow{3}{*}{ 4th Class } & 1st Class & $22,152^{*}$ &, 000 \\
\cline { 2 - 4 } & 2nd Class & 7,083 &, 084 \\
\cline { 2 - 4 } & 3rd Class & $8,099^{*}$ &, 006 \\
\hline
\end{tabular}

* The mean difference is significant at the 0.05 confidence level.

\title{
5. Result
}

Financial literacy, in short, is that people have the knowledge and skills to make their individual financial decisions correctly. With the diversification of products and services in financial markets, the importance of individuals being financially literate has increased. In this context, increasing financial literacy has become one of the issues that the country's governments emphasize. Acquiring financial literacy at an early age will enable the individual to make the right financial decisions throughout his/her life. As with the university students included in this research, university students who live separately from their families for the first time in their lives trying to live with a limited budget. For this reason, university students need to have a high level of financial literacy to maintain a productive education life.

In this study, the data obtained from the survey conducted to measure the financial literacy levels of 400 students studying at the Faculty of Economics and Administrative Sciences of Hitit University were used. By using the percentages of correct answers given to the questionnaire, general success scores were determined based on the question and test group. The average success score of all participants was found to be 47. In the study of Kilıç et al. (2015) to determine the financial literacy levels of students studying in various faculties at Gaziantep University, the average success score was found to be 48 , which is consistent with the results of this study. The average achievement score of male students was calculated as 49 , and the average achievement score of female students was calculated as 45 . However, as a result of the T-test, no significant difference was found between the scores of male and female students. The finding that female students have lower financial literacy than male students was also found in the studies of Chen and Volpe (1998), Lusardi and Mitchell (2008), Onea and Dornean (2012), Agnew and Harrison (2015). The results obtained from this study are also consistent with the aforementioned studies.

When the students participating in the research were grouped according to their classes, it was determined that the final year students had the highest financial literacy scores (53 points). It was found that the financial literacy scores of the first-year students were the lowest (31 points). When the students were grouped according to the departments they studied, it was determined that the students studying in the Banking and Finance department got the highest score with 59 points. It was seen that the students studying in the department of economics took second place with 49 points. It has been determined that students studying in the department of political science and public administration have the lowest score with 39 points. According to the results obtained from this study, it is understood that the financial literacy levels in the departments where the courses to develop financial knowledge and skills are given more intensively. The findings of Ergün's (2018) research on university students in 8 European countries also revealed that financial information courses have a positive effect on financial literacy. As a result of the 


\author{
(online) = ISSN $2285-3642$ \\ ISSN-L = $2285-3642$ \\ Journal of Economic Development, Environment and People \\ Volume 10, Issue 4, 2021 \\ URL: http://jedep.spiruharet.ro \\ e-mail: office jedep@spiruharet.ro
}

analysis, it has been determined that there is no significant difference between the students' use of credit cards and internet banking and their financial literacy.

When the questions directed to the students are grouped, it is seen that the group with the highest score is on tax and legislation knowledge, followed by financial calculation questions. It has been determined that the average score of the investment and financial information questions is at the lowest level. This situation reveals that the students of the Faculty of Economics and Administrative Sciences of Hitit University do not have sufficient knowledge of basic finance and that the curriculum of the faculty should be enriched with courses that will provide students with investment and finance information.

\title{
6. References
}

[1] AGNEW, S. ve HARRISON, N.(2015), Financial literacy and student attitudes to debt: A cross national study examining the influence of gender on personal finance concepts, Journal of Retailing and Consumer Services, 25 (2015) 122-129.

[2] Alkan, O., Oktay, E., Unver, S., \& Gerni, E. (2020). Determination of factors affecting the financial literacy of university students in Eastern Anatolia using ordered regression models. Asian Economic and Financial Review, 10(5), 536.

[3] ANBAR, A., \& BERIDZE, J. (2020). Üniversite Öğrencileri Arasında Finansal Okuryazarlık: Türkiye Ve Gürcistan Karşılaştırması. Yüksel AKAY UNVAN \& Faruk KALAY (Editörler). İktisadi ve İdari Bilimlerde Güncel Araştırmalar, Cetinje: IVPE, 19.

[4] BALTACl, N. (2020). Üniversite Öğrencilerinin Finansal Okuryazarlık Seviyelerinin Belirlenmesi Üzerine Bir Araştırma: Doğu Karadeniz Örneği. Gümüşhane Üniversitesi Sosyal Bilimler Enstitüsü Elektronik Dergisi, 11(3), 805-815.

[5] BARMAKi N., (2015). Üniversite Öğrencilerinin Finansal Okuryazarlık Düzeylerinin Belirlenmesine Yönelik Bir Araştırma, Yayımlanmamış Doktora Tezi, Hacettepe Üniversitesi Sosyal Bilimler Enstitüsü, s. 175-176.

[6] BAŞARIR, Ç., \& SARIHAN, A. Y. (2017). Üniversite Öğrencilerinin Finansal Okuryazarliklarinin Belirlenmesi: Bandirma Onyedi Eylül Üniversitesi Örneği. Yönetim ve Ekonomi Araştırmaları Dergisi, 15(Ek Sayı 1), $143-162$.

[7] BAYRAM S. S., Finansal Okuryazarlık ve Para Yönetim Davranışları: Anadolu Üniversitesi Öğrencileri Üzerinde Bir Uygulama, Business \& Management Studies: An International Journal Vol.:2 Issue:2 Year:2014, 105-135.

[8] BiçER, E. B., \& Altan, F. (2016). Üniversite Öğrencilerinin Finansal Okuryazarlık ile İlgili Tutum ve Davranışlarının Değerlendirilmesi. Journal of Graduate School of Social Sciences, 20(4).

[9] BiNGÜL, B. A., TÜRK, A., \& Öz, R. A. (2020). Üniversite Öğrencilerinin Finansal Okuryazarlığı:"Kırklareli Üniversitesi Örneği". Journal of History School (JOHS), 13(44), pp.613-630.

[10] CHEN H., VOLPE R. P.,(1998). An Analysis of Personel Financial Literacy Among College Students, Financial Services Review, 7(2), 107-128.

[11] ERGÜN B., ŞAHIN A. ve ERGIN E. (2014). Finansal Okuryazarlık: İşletme Bölümü Öğrencileri Üzerinde Bir Uygulama, Uluslararası Sosyal Araştırmalar Dergisi, Cilt:7, Sayı: 34.

[12] ERGÜN, K. (2018). Financial literacy among university students: A study in eight European countries. International Jonurnal Consumer Studies. Volume:42, 2 - 15. 


\author{
(online) = ISSN $2285-3642$ \\ ISSN-L = 2285 - 3642 \\ Journal of Economic Development, Environment and People \\ Volume 10, Issue 4, 2021 \\ URL: http://jedep.spiruharet.ro \\ e-mail: office jedep@spiruharet.ro
}

[13] HAYTA, A.B. (2011), Aile Finans Sistemi İlişkileri: Finansman Yönetimi Finansal Okuryazarlık, Ankara: Gazi Kitabevi.

[14] KARAA İ. E., KUĞU T. D., (2016). Determining Advanced and Basic Financial Literacy Relations and Overconfidence, and Informative Social Media Association of University Students in Turkey, Educational Sciences: Theory and Practice, 16(6), December, p. 1865-1891.

[15] KARADENIZ, E., KOŞAN, L., GECGIN, E., \& BEYAZGÜL, M. (2019). Üniversite Öğrencilerinin Finansal Okuryazarlık Düzeylerinin Analizi: Kafkas Üniversitesi Sarıkamış Kampüsünde Bir Araştırma. Manisa Celal Bayar Üniversitesi Sosyal Bilimler Dergisi, 17(2), 325-346.

[16] KAYA, M. \& GÜNEŞ, H. Üniversite Öğrencilerinin Finansal Okuryazarlık Düzeylerinin Analizi: Bankacılık ve Finans Bölümü Öğrencileri Üzerine Bir Uygulama-Analysis of The Financial Literacy Levels Of University Students: An Application on Department of Banking and Finance. Mehmet Akif Ersoy Üniversitesi Sosyal Bilimler Enstitüsü Dergisi, 11(28), 295-305.

[17] KILIÇ Y., ATA, H. A. ve SEYREK I. H. (2015). Finansal Okuryazarlık: Üniversite Öğrencilerine Yönelik Bir Araştırma, Muhasebe ve Finansman Dergisi, Nisan sayısı,sf.129-150.

[18] KOCABIYIK, T., \& TEKER, T. (2018). Finansal Okuryazarlık: Süleyman Demirel Üniversitesi Öğrencileri Üzerine Bir Araştırma. Stratejik ve Sosyal Araştırmalar Dergisi, 2(2), 117-144.

[19] LUSARDI, A., MITCHELL, O.S. and CURTO, V.(2010) Financial Literacy Among The Youngs, Journal of Consumer Affairs, June 2010, 44(2):358-380.

[20] OANEA, D. C., \& Dornean, A. (2012). Defining and measuring financial literacy. New evidence from Romanian'students of the master in finance. Analele stiintifice ale Universitatii "Al. I. Cuza" din lasi. Stiinte economice/Scientific Annals of the" Al. I. Cuza", 59(2), 113-129..

[21] ÖZTÜRK E., DEMIR Y.,(2015), Finansal Okuryazarlık ve Para Yönetimi: Süleyman Demirel Üniversitesi Akademik Personel Üzerine Bir Uygulama, Muhasebe ve Finansman Dergisi, Ekim/2015, s.113-134.

[22] ROSACKER, K. M., ROSACKER, R.E. (2016). An exploratory study of financial literacy training foraccounting and business majors, The International Journal of Management Education, 14, 1-7.

[23] SEZER D. ve DEMiR S., (2015), Yatırımcıların Finansal Okuryazarlık ve Bilişsel Yetenek Düzeylerinin Psikolojik Yanılsamalar ile İlişkisi, Muhasebe ve Finansman Dergisi, Nisan/2015,s. 69-88.

[24] Süleyman, U. Y. A. R., \& ATALAY, I. Finansal Okuryazarlık ve Üniversitede Verilen Derslerin Finansal Okuryazarlık Üzerine Etkisi. Muhasebe Enstitüsü Dergisi, (64), 1-17.

[25] Thomas, B., \& Subhashree, P. (2020). Factors that influence the financial literacy among engineering students. Procedia Computer Science, 172, 480-487.

[26] YAMANE, T. (2010). Temel Örnekleme Yöntemleri, İstanbul: Literatür Yayınevi, 3. Baskı, s. 498. 